\title{
Changes in Vascular Flora of the Rzeszow Reservoir after 20 Years (SE Poland)
}

\author{
Maria Ziaja*, Tomasz Wójcik \\ Department of Ecology and Nature Protection, University of Rzeszow, \\ Cicha 2a, 35-326 Rzeszow, Poland \\ Received: 16 December 2014 \\ Accepted: 28 January 2015
}

\begin{abstract}
The flora and vegetation of river valleys are currently greatly transformed as a result of the increased influence of many factors related to human activity. Earlier research on the vegetation of the Rzeszow Reservoir was carried out in 1994-95. Since then, its depth has been greatly diminished and its surface area decreased two-fold. Moreover, types of land use have changed in the immediate vicinity of the reservoir. In 2011-14 we conducted similar field research aimed at analysing changes in vascular flora. For this purpose, we compared indices of anthropogenic changes in flora for both study periods. Our results show that the flora of this area is diverse in taxonomic, syntaxonomic, and ecological terms. It includes both typical aquatic plants and species characteristic for the habitats surrounding the water body. Currently, 327 vascular plant species of 68 families are recorded in the study area. The flora is dominated by hemicryptophytes, with high contributions of therophytes and hydrophytes. In the geographical-historical classification, the dominant groups were spontaneophytes (and among them apophytes), whereas the contribution of anthropophytes was small. This was confirmed by high values of synanthropization and apophytization indices $(>50 \%)$, and the low value of the anthropophytization index (17.4\%). The low index of flora naturalness (24.4\%) attests to its transformation. The socio-ecological spectrum shows high contributions of species typical of alluvial forests: aquatic and tall fen communities (17\%), fertile deciduous forests and shrub communities (14\%), and fresh, moderately moist meadows $(12 \%)$.
\end{abstract}

Keywords: anthropogenic indices, Rzeszow Reservoir, southeast Poland, vascular flora, floristic changes

\section{Introduction}

Transformations of flora and vegetation result from natural processes taking place in the landscape as well as various types of human impact leading to synanthropization of the vegetation [1-3]. The changes are gradually accelerated and their scope and scale are increasing. This results from the growing human pressure on natural communities and their environment [4-6]. All the transformations of plant communities involve also other components of ecosystems.

*e-mail: mziaja@ur.edu.pl
This leads to fundamental changes in functioning of the ecosystems $[7,8]$. The intensity and types of human impact affect the scope and rate of changes, which are reflected in the decline of species typical of natural vegetation and the creation of new anthropogenic communities $[2,3,9,10]$. At early stages of synanthropization, floristic diversity usually increases $[2,8,11,12]$, whereas intensification of human impact usually leads to a decline in diversity [13-16].

River valleys are one of the best models for research on species diversity $[5,17,18]$, the process of synanthropization $[1,17,19,20]$, the dynamics of flora [21], as well as transformations of the vegetation associated with river val- 
leys $[4,16,22,23]$. This results from the high natural diversity of sites $[2,24]$. River valleys play a role of ecological corridors [3, 18, 25-27] and are refuges of biodiversity [3, $8,21,28]$. Sites located along rivers are also exceptionally vulnerable to alien species invasion [18, 29-36]. Artificial water bodies are similar in this respect, and various ecosystems affect them [8, 24, 37]. In Poland, like all over Europe, wetlands are disappearing, which causes the gradual loss of many rare and threatened species of plants and animals $[8$, $16,28,38]$. Harvolk et al. [8] report that in the late $20^{\text {th }}$ century $77 \%$ of rivers in Europe and North America were greatly transformed.

This study aimed at assessing the degree of transformation of the vascular flora of the Rzeszow Reservoir after 20 years. We compared results of research conducted in 199495 with data collected in 2011-14.

\section{Study Area}

The Rzeszow Reservoir is located within the administrative borders of the city of Rzeszow in southeastern Poland. On the ATPOL grid, the study area is located in square FF64 [39]. According to the physiographic division of Poland [40] it lies in the Rzeszow Foothills mesoregion. According to a geobotanical classification of Poland [41], it is within the Sandomierz Forest District in the Sandomierz Basin region, which is part of the subdivision known as the Belt of Submontane Basins. The water body was created in 1973 by damming the Wislok River $63 \mathrm{~km}$ from the river head, as a reservoir of recreational value, with a surface area of 68 ha and water volume of 1.8 million $\mathrm{m}^{3}$ [42]. Field research covered the water body and its immediate vicinity.

Over the last 20 years the reservoir has been greatly transformed. Currently, as a result of intensive sedimentation of material carried by the Wislok and its tributary, the river Strug, the surface area of the reservoir was reduced by about 38 ha, and large parts of the water body are much shallower now. The proportion of shrub communities and tall fens has increased, while the adjacent areas have been managed for tourism and recreation (Fig. 1). In the first study period (1994-95), the vicinity of the reservoir was dominated by green areas (meadows, lawns, wastelands, and patches of arable fields), which jointly covered ca. $85 \%$ of the total area along the shore, while recreational areas accounted for only $10 \%$ and $5 \%$ housing. In the second study period (2011-14), the contribution of recreational areas was about three-fold higher (ca. 30\%), and ca. 15\% of the immediate vicinity of the reservoir were used for housing. Also, the qualitative and quantitative composition of the remaining green areas (55\%) was changed, as they are now dominated by lawns and wastelands. In recent years, the vicinity of the reservoir has been adapted for recreational purposes, cycle lanes have been built on both sides of the reservoir, as well as playgrounds, a sandy beach, and food and beverage outlets.

Rzeszow Reservoir is part of the proposed Natura 2000 site named "Middle Wislok River with tributaries" (PLH 180030). The area of 1064.6 ha starts from the dam in
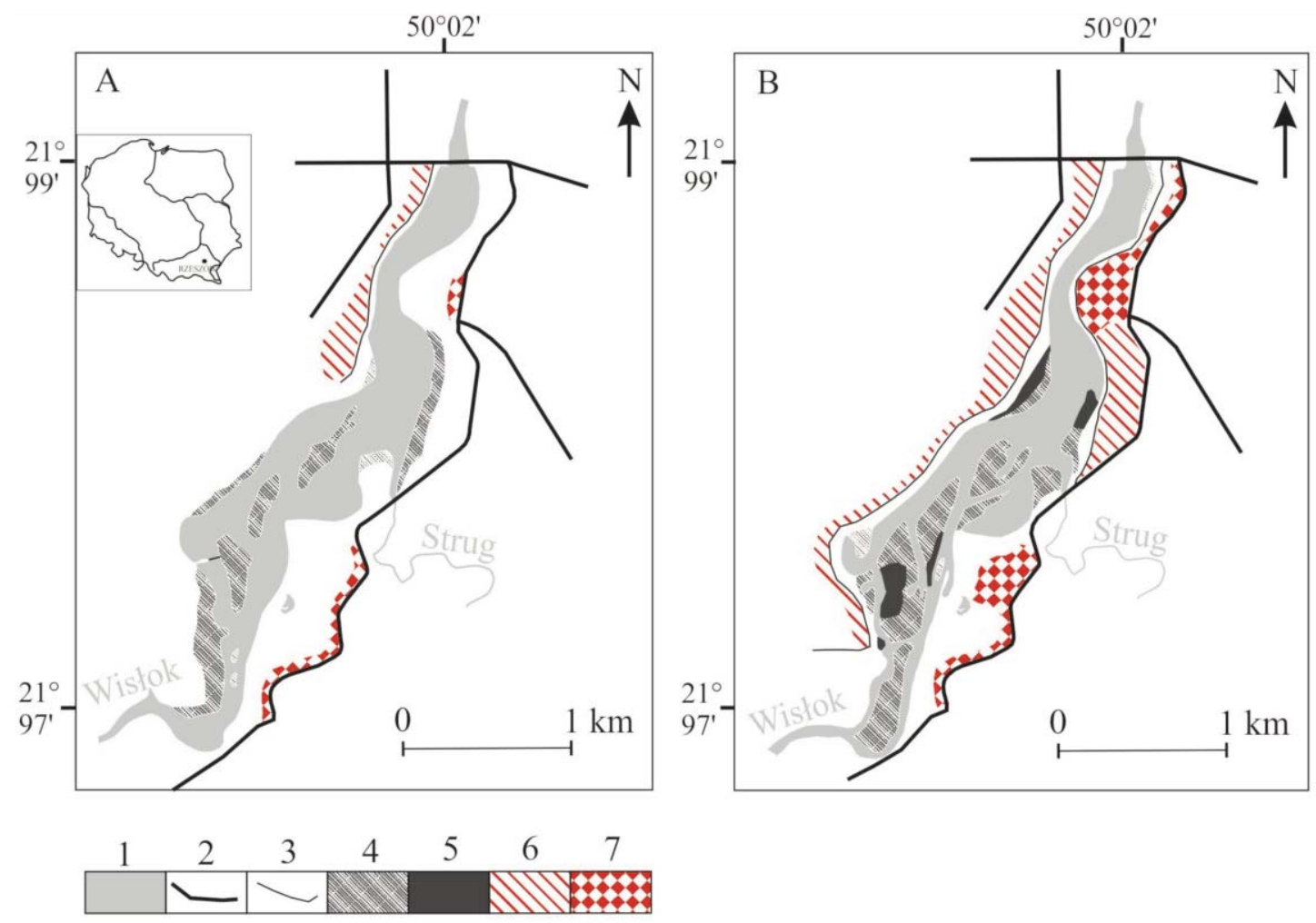

Fig. 1. Map of the study area in 1994-95 (A) and 2011-14 (B): 1 - waters/reservoir, 2 - roads, 3 - walking/cycling paths, 4 - tall fen communities, 5 - communities of trees and shrubs, 6 - recreational area, 7 - housing. 
Besko (where the montane section ends) and encompasses the Jaslo-Krosno Basin, Strzyzow Foothills, and Dynow Foothills, ending with the reservoir. The area was designated mostly for protection of valuable fish species, as the ichthyofauna of the river consists of over 30 species, including 10 protected ones [43].

\section{Material and Methods}

In 1994-95, vascular flora were investigated in the reservoir [44], and the results can be used for comparison with data collected during our field research in 2011-14. We investigated aquatic and waterside vegetation as well as communities adjacent to the reservoir. Plant names follow Mirek et al. [45], while names of families follow Rutkowski [46]. In the floristic analysis we used the Raunkiaer system of plant life-forms [47]. The geographical-historical classification is based on the concept of Kornaś [48], and the following groups were distinguished: apophytes [49], archaeophytes [50-53], and kenophytes [32]. The flora is divided into two groups: spontaneophytes (native species, within the natural geographic range) and anthropophytes (alien species). Native species are subdivided into non-synanthropic spontaneophytes ( $\mathrm{Sp}$, found exclusively on natural sites), and apophytes (Ap, species colonizing disturbed and transformed sites). Anthropophytes are represented by archaeophytes, kenophytes, and diaphytes. The socio-ecological classification is based on Jackowiak's concept [54], while assigning to individual groups is based on Matuszkiewicz's [55] phytosociological classification.

To assess the effects of human activity on the plant cover of the study area, we calculated indices of anthropogenic changes in flora: the total synanthropization index $\mathrm{WS}_{\mathrm{t}}$ (percentage contribution of apophytes and anthropophytes to the total number of species), total apophytization index $\mathrm{WAp}_{\mathrm{t}}$ (percentage contribution of apophytes to the total number of species), spontaneophyte apophytization index Wap (percentage contribution of apophytes to the total number of native species), total anthropophytization index $\mathrm{WAn}_{\mathrm{t}}$ (percentage contribution of anthropophytes to the total number of species), total archaeophytization index $\mathrm{WAr}_{\mathrm{t}}$ (percentage contribution of archaeophytes to the total number of species), total kenophytization index $\mathrm{WKn}_{\mathrm{t}}$ (percentage contribution of kenophytes to the total number of species), flora modernization index WM (percentage contribution of kenophytes to the total number of permanent anthropophyte species), and flora naturalness index WN (percentage contribution of non-synanthropic spontaneophytes to the total number of species) $[7,54]$.

\section{Results}

The recently documented vascular flora of the reservoir consists of 327 species, compared to 213 in 1994-95. However, only 162 species were recorded in both study periods. We failed to find 51 of the species recorded in 1994-95, but instead we recorded 165 new species. The number of represented families increased remarkably, from 49 to 68. Thus we found plants from 21 new families, including: Anacardiacaceae, Anagraceae, Araceae, Butomaceae, Cannabaceae, Celastraceae, Cornaceae, Corylaceae, Grossulariaceae, Iridaceae, Lentibulariaceae, Oleaceae, Oxalidaceae, Rhamnaceae, Tiliaceae, Trapaceae, Ulmaceae, Verticaceae, Valerianaceae, Verbenaceae, and Vitaceae. Recent field research did not confirm the presence of two families: the Campanulaceae and Gentianaceae. Among the recorded families, 11 were represented by the largest number of species and accounted for $>50 \%$ of the flora in each of the study periods. The richest families include the Poaceae (38 species), Asteraceae (32 species), Fabaceae (25 species), and Rosaceae (23 species). In some families, the number of species increased substantially, e.g. in the Rosaceae $(+19$ species), Poaceae $(+14$ species), Caryophyllaceae ( +7 species), and Asteraceae $(+6$ species) (Fig. 2).

Considering plant life-forms (Fig. 3), the flora of the Reservoir in both study periods was dominated by hemicryptophytes (51\% in 1994-95 and 49\% in 2011-14). This group included 70 new taxa, which were not recorded

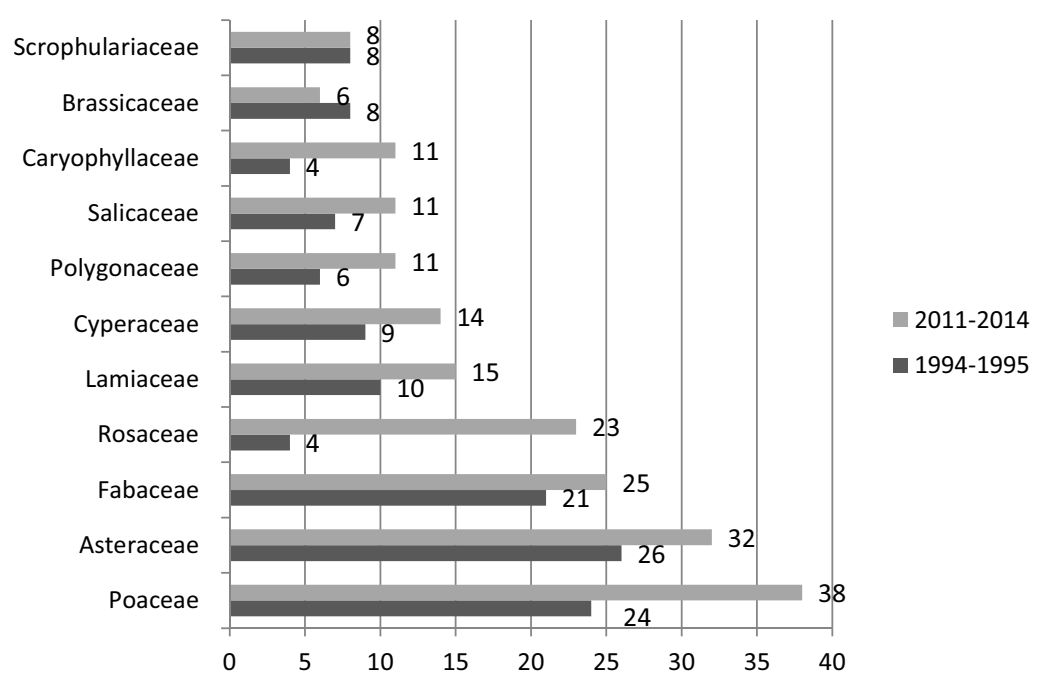

Fig. 2. Contributions of the most species-rich families to the flora of Rzeszow Reservoir. 
previously, e.g. Agrostis stolonifera, Althaea officinalis, Carex cuprina, C. paniculata, C. spicata, Dianthus deltoides, Hieracium bauhinii, Valeriana sambucifolia, and Verbena officinalis. Therophytes ranked second (16.5\% and $13.5 \%$, respectively), while hydrophytes ranked third ( $15.5 \%$ and $11.0 \%$, respectively). Among hydrophytes, the occurrence of eight species was not confirmed in this study (Batrachium circinatum, Bolboschoenus maritimus, Ceratophyllum submersum, Lemna gibba, Myriophyllum verticillatum, Potamogeton crispus, P. nodosus, and Scolochloa festucaceae), but 12 new ones were recorded (Butomus umbellatus, Carex pseudocyperus, Ceratophyllum demersum, Hydrocharis morsum-ranae, Iris pseudacorus, Leersia oryzoides, Myriophyllum spicatum, Polygonum amphibium, Potamogeton perfoliatus, Sium latifolium, Trapa natans, and Utricularia vulgaris). Among annual species (therophytes), as many as 25 new species appeared, whereas 15 of the species reported previously seem to be absent. In the second study period, contributions of megaphanerophytes (trees) and nanophanerophytes (shrubs) increased considerably, as compared to the earlier period. These groups include as many as 44 new species, and their percentage contributions are now doubled. In both study periods, only small proportions of the flora of the reservoir were contributed by geophytes and chamaephytes.

In research on anthropogenic transformations of flora, the geographical-historical classification is used most often (Table 1). In both study periods, native species overwhelmingly dominated (87\% in $1994-95$ and $83 \%$ in $2011-14$ ) over anthropophytes. However, after 20 years the contribution of this group declined, although the absolute number of species in the group increased. The group of native taxa includes apophytes (synanthropic spontaneophytes), recorded primarily in waterside habitats modified by human activity, and non-synanthropic spontaneophytes, found in natural and slightly transformed habitats, i.e. in open water, in the littoral zone, and in the immediate vicin-
Table 1. Contributions of geographical-historical groups to the flora of the reservoir.

\begin{tabular}{|l|c|c|}
\hline \multirow{2}{*}{ Geographical-historical groups } & \multicolumn{2}{c|}{$\begin{array}{c}\text { Number of species } \\
\text { recorded in study periods }\end{array}$} \\
\cline { 2 - 3 } & $1994-95$ & $2011-14$ \\
\hline Apophytes & $116(55 \%)$ & $190(58 \%)$ \\
\hline Non-synanthropic spontaneophytes & $69(32 \%)$ & $80(25 \%)$ \\
\hline Archaeophytes & $13(6 \%)$ & $23(7 \%)$ \\
\hline Kenophytes & $15(7 \%)$ & $34(10 \%)$ \\
\hline - epoecophytes & 4 & 14 \\
\hline - agriophytes & 10 & 19 \\
\hline - ephemerophytes & 1 & 1 \\
\hline Total & 213 & 327 \\
\hline
\end{tabular}

ity of the reservoir. The greatest increase in species diversity was observed among apophytes, especially those typical of meadows (51 new species) and forests (49 new species), but their contribution to the total number of species increased only slightly ( $55 \%$ in the past versus $58 \%$ now). The appearance of such large numbers of new species results from the variety of habitats surrounding the reservoir and the migration of species from adjacent habitats (in both directions). As far as non-synanthropic spontaneophytes are concerned, their contribution to the flora decreased ( $32 \%$ versus $25 \%$ ) while the number of species increased (+27), including e.g. Bidens cernua, Butomus umbellatus, Ceratophyllum demersum, Hydrocharis morsus-ranae, Leersia oryzoides, Myriophyllum spicatum, and Potamogeton perfoliatus. Currently, 16 species of previously reported non-synanthropic spontaneophytes seem to be absent, e.g. Batrachium circinatum, Bolboschoenus maritimus, Ceratophyllum submersum, Cyperus fuscus,

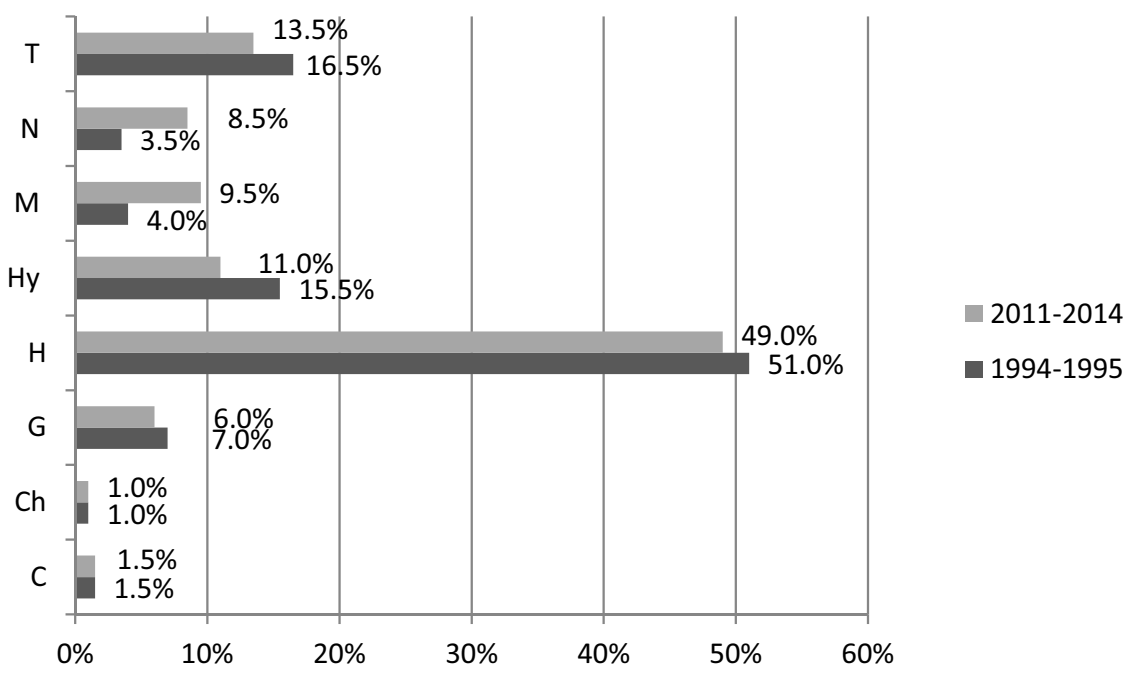

Fig. 3. Comparison of the biological spectrum of species (plant life-forms) in the flora of Rzeszow Reservoir in both study periods. $\mathrm{T}$ - therophytes, $\mathrm{N}$ - nanophanerophytes, $\mathrm{M}$ - megaphanerophytes, Hy - hydrophytes, $\mathrm{H}$ - hemicryptophytes, $\mathrm{G}$ - geophytes, $\mathrm{Ch}$ - nonherbaceous chamaephytes, $\mathrm{C}$ - herbaceous chamaephytes. 
Table 2. Socio-ecological structure of the flora of Rzeszow Reservoir in both study periods.

\begin{tabular}{|c|c|c|}
\hline \multirow{2}{*}{ Socio-ecological group } & \multicolumn{2}{|c|}{ Number of species recorded in study periods } \\
\hline & $1994-95$ & $2011-14$ \\
\hline Cl: Querco-Fagetea, Rhamno-Prunetea & $12(6 \%)$ & $47(14 \%)$ \\
\hline Cl: Quercetea robori-petraea, Epilobietea angustifolii, Nardo-Callunetea & $6(3 \%)$ & $11(3 \%)$ \\
\hline O: Glechometalia hederaceae & $3(1 \%)$ & $12(4 \%)$ \\
\hline Cl: Festuco-Brometea, Trifolio-Geranietea sanguinei & $15(7 \%)$ & $17(5 \%)$ \\
\hline $\mathrm{Cl}$ : Koelerio glaucae-Corynephoretea canescentis & $5(2 \%)$ & $5(2 \%)$ \\
\hline $\mathrm{Cl}$ : Alnetea glutinosae & $3(1 \%)$ & $4(1 \%)$ \\
\hline Cl: Salicetea purpurea, Phragmitetea, Potametea, Lemnetea minoris & $47(22 \%)$ & $56(17 \%)$ \\
\hline O: Molinietalia & $11(5 \%)$ & $19(6 \%)$ \\
\hline O: Arrhenateretalia, $\mathrm{Cl}$ : Molinio-Arrhenateretea & $26(12 \%)$ & $39(12 \%)$ \\
\hline O: Trifolio fragiferae-Agrostietalia stoloniferae, Plantaginetealia majoris & $19(9 \%)$ & $18(6 \%)$ \\
\hline $\mathrm{Cl}$ : Bidentetea tripartiti, Isöeto-Nanojuncetea, Betulo-Adenostyletea & $8(4 \%)$ & $10(3 \%)$ \\
\hline O: Artemisietalia vulgaris, Convolvuletealia sepium & $17(8 \%)$ & $22(7 \%)$ \\
\hline O: Onopordetalia acanthii, $\mathrm{Cl}$ : Agropyretea intermedio-repentis & $11(5 \%)$ & $14(4 \%)$ \\
\hline O: Sisimbrietalia & $10(5 \%)$ & $7(2 \%)$ \\
\hline O: Centauretalia cyani, Polygono-Chenopodietalia, Cl: Stellarietea mediae & $12(6 \%)$ & $24(7 \%)$ \\
\hline Others & $8(4 \%)$ & $22(7 \%)$ \\
\hline Total & 213 & 327 \\
\hline
\end{tabular}

Lemna gibba, Myriophyllum verticillatum, Potamogeton crispus, and P. nodosus. In the study area, also the contribution of alien species increased (6\% versus $7 \%$ for archaeophytes and $7 \%$ versus $10 \%$ for kenophytes), as compared with the previous study period. Anthropophytes are currently dominated by kenophytes, and the number of species in this group was nearly doubled, including mostly trees and shrubs, e.g. Juglans aliantifolia, Ligustrum vulgare, Fraxinus pennsylvanica, Padus serotina, Quercus rubra, Robinia pseudoacacia, Rosa multiflora, Spiraea salicifolia, etc. Archaeophytes included common weeds, such as Anagallis arvensis, Echinochloa crus-galli, Lathyrus tuberosus, Capsella bursa-pastoris, Papaver rhoeas, Matricaria maritima ssp. inodora, Sonchus asper, S. oleraceus, etc. In 2011-14 we found 36 anthropophyte species that were not recorded in the earlier study period. These include 21 kenophytes and 15 archaeophytes.

In the socio-ecological (phytosociological) classification of the reservoir flora, 16 groups were distinguished (Table 2). Analyzing the vascular flora of the reservoir in respect to their habitat preferences, we found that the major groups are species associated with alluvial forests as well as aquatic and tall fen communities of the classes Salicetea purpurea, Phragmitetea, Potametea, and Lemnetea minoris. They currently account for $17 \%$ of the total number of species, compared to $22 \%$ in the previous study period, but the number of species increased. No change was observed in the contribution of species typical of forest clearings (classes Epilobietea angustifolii and NardoCallunetea), dry sandy grasslands (class Koelerio glaucaeCorynephoretea canescentis), and alder forests (class Alnetea glutinosa), although the number of recorded species is now higher. A large increase is noticeable in the number of species representing fresh, moderately moist meadows (class Molinio-Arrhenatheretea, order Arrhenateretalia), but again the percentage contribution of this group did not change in relation to the previous study period. During the last 20 years, contributions of species of fertile deciduous forests (class Querco-Fagetea) and shrub communities (class Rhamno-Prunetea) substantially increased. This group now includes 37 new species, so its contribution increased from $6 \%$ to $14 \%$. A higher contribution is currently recorded also for plants of nitrophilous shrub communities and forest edges (order Glechometalia hederaceae). Contributions of species of moist meadow communities (order Molinietalia) and segetal, i.e. field weed communities (orders Centauretalia cyani and Polygono-Chenopodietalia) increased only slightly, although 17 new species of this group were found. Lower contributions are currently recorded for xerothermic grasslands and forest edge communities (classes FestucoBrometea and Trifolio-Geranietea sanguinei), nitrophilous floodplain grasslands and heavily trampled plant communities (orders Trifolio fragiferae-Agrostietalia stoloniferae and Plantaginetealia majoris), therophytes on wet sites (classes Bidentetea tripartiti, Isöeto-Nanojuncetea and 


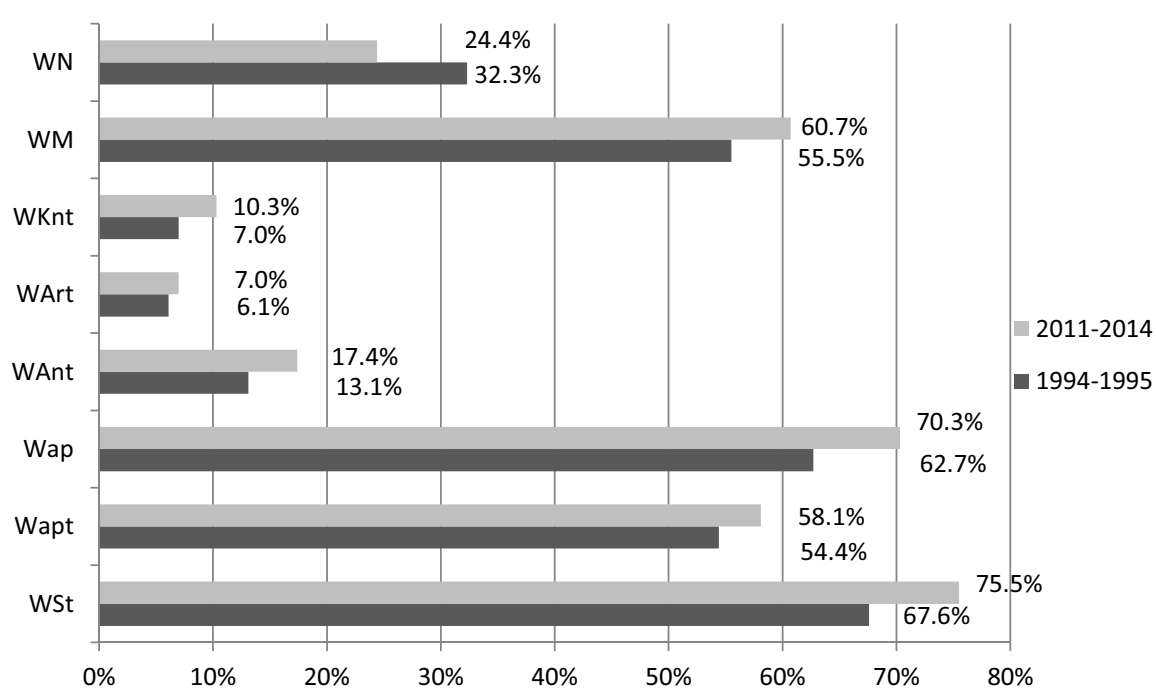

Fig. 4. Indices of anthropogenic changes in the flora of Rzeszow Reservoir.

$\mathrm{WS}_{\mathrm{t}}$ - total synanthropization index, WAp $\mathrm{p}_{\mathrm{t}}$ total apophytization index, Wap - spontaneophyte apophytization index, WAn $n_{\mathrm{t}}-$ total anthropophytization index, $\mathrm{WAr}_{\mathrm{t}}$ - total archaeophytization index, $\mathrm{WKn}_{\mathrm{t}}$ - total kenophytization index, $\mathrm{WM}$ - modernization index, $\mathrm{WN}$ - naturalness index.

Betulo-Adenostyletea), and ruderal communities (orders Artemisietalia vulgaris, Convolvuletealia sepium, Onopordetalia acanthii, Sisymbrietalia, and class Agropyretea intermedio-repentis). In the present flora of the reservoir, species of undetermined phytosociological affiliation accounted for $7 \%$ of the flora, i.e. the number of species and their contribution to the flora increased, as compared to the earlier study period.

During recent field research, we found six protected species [56], including 5 new ones: Ribes nigrum, Viburnum opulus, Dianthus armeria, Trapa natans, and Utricularia vulgaris. We failed to find two of the species reported previously (Centaurium erythraea and Gentiana asclepiadea), but we confirmed the occurrence of an orchid (Epipactis helleborine). Interestingly, we also discovered a rare aquatic plant, Trapa natans, whose population develops dynamically in the favourable environmental conditions. On the scale of Poland it is classified as critically endangered, CR [57, 58]. The local population is probably of anthropogenic origin, as there are no published data about the occurrence of this species in the reservoir and in its vicinity [59]. Research in European lakes confirms that this species tolerates eutrophication [38].

Comparison of values of the indices allowed us to describe the flora in respect to the degree of naturalness and the scope of human transformation. The greater the percentage contribution of non-synanthropic spontaneophytes, the more natural is the given area, whereas a high percentage contribution of anthropophytes to the flora points to advanced processes of decline of native species in the analysed area. Considerable differences in floristic composition of the study area were visible when we analysed individual indices of anthropogenic transformation. The anthropophytization index was low in both periods, but it is slightly higher now than during the earlier study (Fig. 4).

Values of archaeophytization index were low, reflecting the lack of older introduced species, including weeds. For over 20 years the kenophytization index increased due to the easy spread of neophytes along river valleys, often of invasive species. The closely related modernization index of the flora is now higher $(55.5 \%$ versus $60.7 \%)$. The increase in apophytization index (62.7\% versus $70.3 \%)$ points to the transformation of natural sites and expansion of species from adjacent habitats, usually forests and meadows. Attention should be paid to the lower index of naturalness ( $32.3 \%$ versus $24.4 \%$ ), and the simultaneous rise in the number of non-synanthropic spontaneophytes. The total synanthropization index was high and within 20 years it reached $75.5 \%$ compared to the previous $67.6 \%$.

\section{Discussion}

Most of the available publications on changes in flora under the influence of human activity are concerned with urban areas [54], farmlands [60], lakes [38, 61, 62], and rivers $[2,6,16,22,63]$. Only a few publications present results of long-term monitoring of anthropogenic changes in flora of rivers or dam reservoirs $[1,4,16,61,64]$. Comparison of flora of the same area in different years allows us to assess the degree of transformation $[4,64,65]$. The natural character of the river valley environment or the varying degree of transformations caused by human activity is reflected in their floristic and phytosociological composition [1,62].

The analysis of flora in respect of changes due to anthropogenic factors is of great importance for assessment of its naturalness and resistance of habitats to invasion by alien species $[36,66]$. Floristic research may be used to determine environmental conditions and to monitor changes $[16,64]$. Plant species - because of their diversity, life forms, geographic distribution, and ecology - are useful tools for research on ecosystems [64, 67]. The flora naturalness index is a measure of transformations, with high 
values indicating slight changes in flora. In the study area during the last 20 years this index decreased remarkably, and now equals $24.4 \%$. In comparison, Chmiel's [60] results from the NE part of the Wielkopolska region (W Poland), show that values of this index are the highest in nature reserves $(45.5 \%)$, while for the whole investigated area its value equals $32.6 \%$. A decrease in naturalness index was also observed by Gołdyn [1] in the rural landscape of western Poland, where it is now estimated at $51.5 \%$. The degree of transformation of flora and vegetation under the influence of human activity is illustrated by synanthropization and anthropophytization indices, which are currently some of the most objective measures of changes in flora [7, 54].

Synanthropization may result in the decline or disappearance of many native species with narrow ecological ranges and floristic homogeneity, as the remaining species have broad ecological spectra and are tolerant of environmental changes $[4,8]$, or invasive alien species will appear $[18,68,69]$. In the study area, the total synanthropization index reached $75.5 \%$, so it was much higher than previously. A large increase in this index $(48.5 \%)$ was also noted by Gołdyn [1] in western Poland after 30 years. For NE Wielkopolska, Chmiel [60] reported a much lower value of this index: 56.1. A similar increase in the number of synanthropic species was recorded after 30 years by Ceschin et al. [64] in the Tiber valley in Rome. The process of synanthropization is in fact composed of two parallel processes: apophytization and anthropophytization. Apophytization of vegetation was started earlier, as it is linked with the older forms of human pressure [70].

The contribution of alien species (anthropophytes) is most often correlated with the degree of transformation of ecosystems [65]. In the study area, the total anthropophytization index now equals $17.1 \%$, so it is higher than previously. Similar results were reported by Krawczyk [19] from the lower San Valley, where this index reached a mean value of $18.1 \%$. Rzeszow Reservoir, although located within a city and exposed to strong human pressure, has a low value of anthropophytization index.

As far as the kenophytization index is concerned, urban areas are distinguished by the high contribution of newcomers [63] as well as specificity of dam reservoirs [24]. The index reaches high values also in waterside ecosystems $[17,20]$. In the study area it amounted to $10.3 \%$, so it was higher than 7.1\% in the San River Valley [19], and 7.3\% in NE Wielkopolska [60]. In Rzeszow Reservoir the archaeophytization index was low (7\%). Its values are usually low in urban areas, while high in rural areas, as weeds are abundant there $[1,19,60]$. The high modernization index $(60.7 \%)$ in the study area reflects the presence of many newcomers among alien species. High values of this index were recorded also by Krawczyk [19] in the San Valley, where it reached up to $100 \%$ in urban habitats, while the mean value for the lower San Valley was $41.3 \%$. Also in northeastern Spain an increased number of invasive species was observed after 30 years, but the species are not common and are a problem only on a local scale, in contrast to Denmark and California [16]. In the Tiber, the number of alien species after 30 years was $24.0 \%$ higher [64]. This is connected with the role of rivers in the spread of kenophytes, including invasive species, as reported in many publications [4, 15, 29, 31, 35, 71, 72]. Research conducted by Chappuis et al. [16] shows that most invasive species are found in artificial water bodies or river valleys strongly transformed by human activity. Watersides are particularly vulnerable to the invasion of alien species because of disturbances of the littoral zone of river banks [3, 69, 73]. Research in the European Union indicates that invasions by alien species are observed on anthropogenic, urban, waterlogged, and freshwater habitats [34], causing remarkable environmental and economic effects [68]. In the process of synanthropization of flora, an important role is played by apophytization, which is associated with the ability of the large group of native species to colonize habitats strongly disturbed by human activity. Also in this case we recorded higher values of apophytization index (58.1\%) and spontaneophyte apophytization index $(70.3 \%)$ than in the earlier study period. Similar results were obtained in western Poland, where this index increased from $31.0 \%$ to $43.2 \%$ [1]. This is linked with the diversity of plant communities in the vicinity of the reservoir, the nearby forest reserve, and meadow ecosystems.

In respect to flora, we observed shrinking of the ranges of native stenotopic species, and at the same time the spread of native synanthropic plants (apophytes) [4, 64]. According to Jackowiak [74], the growth of apophytes, which migrate from their natural habitats and colonize secondary habitats, points to the process of ecological expansion. Apophytization does not exert any strong effect on qualitative changes in flora, but it attests to the adaptive potential of some species. In contrast, the invasion of the native flora by alien species causes changes in its character [3]. In this way, local biodiversity is increased, but at the same time proportions are changed: the rise in the contribution of anthropophytes is linked with a reduced contribution of native species [35].

There are various causes of changes in the flora of the reservoir, e.g. the intensive penetration of this area by inhabitants as well as its economic development and adaptation for recreation. An important role is also played by the progressive eutrophication of the reservoir, which has led to a decrease in its depth and surface area. This process is observed in many parts of Europe as a result of a remarkable increase in nutrient loads from sewage and surface runoff from arable fields [2, 4, 62, 64]. River valleys are characterized by a high degree of complexity and patchiness of habitats, and consequently also of vegetation $[3,8$, $24,35]$. The increased number of phanerophytes in the study area is associated with the natural process of succession. They are most commonly colonized by Acer, Populus, Fraxinus, and Salix species. Forest communities play an important role in river valley habitats and in regulation of water flow [5]. An increased number of species of trees and shrubs, and particularly of Salix species, was reported by Lyashenko [61], who observed also the spread of tall fen vegetation, which resulted from the great accumulation of sediments and smaller water depth. Vegetation of river val- 
leys plays an important role in maintenance of many functions of ecosystems, including the control of river bank erosion, thermal regulation, nutrient filtration and retention, maintenance of water quality and habitats for animals, but also as a factor of aesthetic and recreational value [75]. The changes can be magnified by human activity $[76,77]$.

The dynamics of waterside habitats also are caused by river flow, climatic factors, and connections between biotic and abiotic factors $[2,26,78,79]$. The analysis of recent data indicates that at the early stages of synanthropization of plant cover, floristic diversity increases as a result of the development of small patches of anthropogenic vegetation within natural plant communities [12]. Harvolk et al. [8], who studied rivers in northwestern Germany, reported that species diversity is $10.0 \%$ higher in artificial channels than in natural rivers. This results from the greater variety of habitats located along channels and their colonization by species that are more tolerant and associated with a high degree of niche variation. In the flora apophytes then appear, i.e. native species that are ecologically alien to the given habitat type. A similar phenomenon is observed in the study area, where floristic diversity increased remarkably, especially in the group of apophytes. This is confirmed by results of other authors [1, 19, 24], who showed that in relation to the diversification of habitats and land use, floristic richness also is enhanced [8].

\section{Conclusions}

1. Over a period of 20 years in Rzeszow Reservoir and its immediate vicinity, the total number of recorded species increased from 213 to 327 . The new species were primarily apophytes and alien species. The rise in total plant diversity at the landscape level was accompanied by a decline of natural communities characteristic of river valleys. Because of the open character of the communities they are easily accessible to newcomers, including kenophytes, which is confirmed by the high flora modernization index (60.7\%).

2. The flora of the reservoir have been greatly transformed, as evidenced by the reduction of the naturalness index ( $32.3 \%$ versus $24.4 \%$ ). The observed transformations of vegetation indicate that the types of land use in the areas along the edges of the reservoir have changed remarkably. This is associated with the growing number of buildings and infrastructure for tourism and recreation. The rising importance of recreation has led to limitations of natural communities. The currently higher values of synanthropization index (75.5\%) and anthropophytization $(17.4 \%)$ of the flora result from strong human impact.

3. One of the major changes was the increase in percentage contributions of species of fertile deciduous forests and shrub communities, as well as plants of nitrophilous shrub communities and forest edges. In those parts of the study area where the plant cover was best preserved, the patches of vegetation corresponded well to the site conditions and were close to natural aquatic and tall fen communities and alluvial forests, but their percentage contribution decreased in the last 20 years.

4. Qualitative and quantitative changes in the vascular flora of Rzeszow Reservoir depend on many factors, primarily on the decrease in surface area of the water body, silt deposition, increased cover of shrub communities and tall fens, and changes in land use in adjacent habitats.

5. Because of the environmental value of the Wislok River Valley and Rzeszow Reservoir on the regional and larger scale, the rate and directions of environmental changes in this area should be monitored.

\section{References}

1. GOŁDYN A. Changes in plant species diversity of aquatic ecosystems in the agricultural landscape in West Poland in the last 30 years. Biodivers. Conserv. 19, (1), 61, 2010.

2. FERNÁNDEZ-ALÁEZ F., FERNÁNDEZ-ALÁEZ M., GARCIÁ-CRIADO F. Spatial distribution pattern of the riparian vegetation in a basin in the NW Spain. Plant Ecol. 179, (1), 31, 2005.

3. STRAYER D.L., FINDLAY S.E.G. Ecology of freshwater shore zones. Aquat. Sci. 72, (2), 127, 2010.

4. MÄEMETS H., PALMIK K., HALDNA M., SUDNITSYNA D., MELNIK M. Eutrophication and macrophyte species richness in the large shallow North-European Lake Peipsi. Aquat. Bot. 92, (4), 273, 2010.

5. STELLA J.C., RODRIGUEZ-GONZÁlEZ P.M., DUFOUR S., BENDIX J. Riparian vegetation research in Mediterranean-climate regions: common patterns, ecological processes, and considerations for management. Hydrobiologia 719, (1), 291, 2013.

6. CAVAIllÉ P., DOMMANGET F., DAUMERGUE N., LOUCOUGARAY G., SPIEGELBERGER T., TABACCHI E., EVETTE A. Biodiversity assessment following a naturality gradient of riverbank protection structures in French Prealps rivers. Ecol. Eng. 53, 23, 2013.

7. FUDALI E. Anthropogenic changes in ecosystems. Transformations of the vegetation. Wydawnictwo Uniwersytetu Przyrodniczego: Wrocław, pp. 1-78, 2009 [In Polish].

8. HARVOLK S., SYMMANK L., SUNDERMEIER A., OTTE A., DONATH T.W. Can artificial waterways provide a refuge for floodplain biodiversity? A case study from North Western Germany. Ecol. Eng. 73, 31, 2014.

9. DE BLOIS S., DOMON G., BOUCHARD A. Environmental, historical and contextual determinants of vegetation cover: a landscape perspective. Landscape Ecol. 16, 421, 2001.

10. BENJAMIN K., DOMON G., BOUCHARD A. Vegetation composition and succession of abandoned farm land: effects of ecological, historical and spatial factors. Landscape Ecol. 20, 627, 2005.

11. KLADIS G., PANITSA M., TSIRIPIDIS I., SARRIS D., DIMOPOULOS P. Vegetation ecology and diversity relationships in a riparian forest remnant of Western Greece. Journal of Biological Research-Thessaloniki 16, 237, 2011.

12. CHESTER E.T., ROBSON B.J. Anthropogenic refuges for freshwater biodiversity: Their ecological characteristics and management. Biol. Conserv. 166, 64, 2013.

13. BROOKS T. M, MITTERMEIER R. A., MITTERMEIER C. G., DA FONSECA G.A.B., RYLANDS A.B., KON- 
STANT W.R., FLIK P., PILGRIM J., OLDIFELD S. MAGIN G., HILTON-TAYLOR C. Habitat loss and extinction in the hotspots of biodiversity. Conserv. Biol. 16, (4), 909, 2002.

14. POSCHOLD P., BAKKER J.P., KAHMEN S. Changing land use and its impact on biodiversity. Basic Appl. Ecol. 6, 93, 2005.

15. HEJDA M., PYŠEK P. JAROŠIK V. Impact of invasive plants on the species richness, diversity and composition of invaded communities. J. Ecol. 97, 393, 2009.

16. CHAPPUIS E., GACIA E., BALLESTEROS E. Changes in aquatic macrophyte flora over the last century in Catalan water bodies (NE Spain). Aquat. Bot. 95, (4), 268, 2011.

17. KUCHARCZYK M. Phytogeographical roles of Lowland Rivers on the example of the Middle Vistula. Maria CurieSkłodowska University Press: Lublin, pp. 127, 2003.

18. ALTERMATT F. Diversity in riverine metacommunities: a Network perspective. Aquat. Ecol. 47, (3), 365, 2013.

19. KRAWCZYK R. Species richness and synanthropization rates of the vascular flora in the lower San River Valley. Acta Bot. Siles. 7, 63, 2011 [In Polish].

20. KUCHARCZYK M. Analysis of distribution of anthropophytes in the Vistula River valley. In: Phytogeographical problems of synanthropic plants; Zając A., Zając M., Zemanek B. (Ed.), Institute of Botany, Jagiellonian University: Cracow, pp. 295-300, 2003.

21. CZARNECKA B. Plant cover of the Szum river valley (Roztocze, South-East Poland). Acta Soc. Bot. Pol. 74, (1), 43, 2005.

22. RATYŃSKA H. Vegetation in the Warta river Poznan ravine and their anthropogenic transformations. Wydawnictwo Akademii Bydgoskiej im. Kazimierza Wielkiego: Bydgoszcz, pp. 466, 2001 [In Polish].

23. KOWALSKAA. Changes in the vegetation of the floodplain of the middle Vistula river valley in Łomianki commune, a suburban district of Warsaw. Acta Bot. Siles. 7, 5, 2011 [In Polish].

24. SÂRBU A., JANAUER G., SCHMIDT-MUMM U., FILZMOSER P., SMARANDACHE D., PASCALE G. Characterisation of the potamal Danube River and the Delta: connectivity determines indicative macrophyte assemblages. Hydrobiologia 671, (1), 75, 2011.

25. BURKART M. River corridor plants (Stromtalpflanzen) in Central European lowland: a review of poorly understood plant distribution pattern. Global Ecol. Biogeogr. 10, 449, 2001.

26. WARD J.V., TOCKNER K., ARSCOTT D.B., CLARET C. Riverine landscape diversity. Freshwater Biol. 47, 517, 2002.

27. DÉCAMPS H. River networks as biodiversity hotlines. C. R. Biologies 334, (5-6), 420, 2011.

28. MURPHY K.J. Plant communities and plant diversity in softwater lakes of northern Europe. Aquat. Bot. 73, (4), 287, 2002.

29. TICKNER D.P., ANGOLD P.G., GURNELL A., M., MOUNTFORD J.O., SPARKS T. Hydrology as an influence an invasion: Experimental investigations into competition between the alien Impatiens glandulifera and the native Urtica dioica in the UK. In: Plant invasions: Species Ecology and Ecosystem Management; Brundu G., Brock J., Camarda I., Child L., Wade M. (Ed.), Backhuys Publishers: Leiden, The Netherlands, pp. 159-168, 2001.

30. DAJDOK Z., KĄCKI Z. Kenophytes of the Odra riversides. In: Phytogeographical Problem of Synanthropic Plants; Zając A., Zając M., Zemanek B. (Ed.), Institute of Botany, Jagiellonian University: Kraków, pp. 131-136, 2003.
31. KUCHARCZYK M., KRAWCZYK R. Kenophytes as river corridor plants in the Vistula and San River Valley. Teka Kom. Ochr. Kszt. Środ. Przyr. 1, 110, 2004.

32. TOKARSKA-GUZIK B. The Establishment and Spreading of Alien Plant Species (kenophytes) in the Flora of Poland. Wyd. Uniwersytetu Śląskiego: Katowice, pp. 1-192, 2005.

33. HUSSNER A. Growth and photosynthesis of four invasive aquatic plant species in Europe. Weed Res. 49, (5), 506, 2009.

34. PYŠEK P., BACHER S., CHYTRÝ M., JAROŠÍK V. WILD J., GRAPOW C., GASSÓ N., KENIS M., LAMBDON P.W., NENTWIG W., PERGL J., ROQUES A., SÁDLO J., SOLARZ W., VILÀ M., HULME P.E. Contrasting patterns in the invasions of European terrestrial and freshwater habitats by alien plants, insects and vertebrates. Global Ecol. Biogeogr. 19, (3), 317, 2010.

35. STRAYER D.L., FINDLAY S.E.G., MALCOLM H.M., FISCHER D.T., COOTE T. Biodiversity in Hudson River shore zones: influence of shoreline type and physical structure. Aquat. Sci. 74, (3), 597, 2012.

36. OLSON E.R., DOHERTY J.M. Macrophyte diversity-abundance relationship with respect to invasive and native dominants. Aquat. Bot. 119, 111, 2014.

37. WRÓBEL I., ZARZYCKI K. The influence of the Czorsztyn-Niedzica and Sromowce Wyżne reservoirs on the flora and vegetation of the Pieniny Mts. Monografie Pienińskie 2, 131, 2010 [In Polish].

38. PENNING W.E., MJELDE M., DUDLEY B., HELLSTEN S., HANGANU J., KOLADA A., VAN DEN BERG M., POIKANE S., PHILLIPS G., WILLBY N., ECKE F. Classifying aquatic macrophytes as indicators of eutrophication in European lakes. Aquat. Ecol. 42, (2), 237, 2008.

39. ZAJĄC A. Atlas of distribution of vascular plants in Poland (ATPOL). Taxon 27, (5-6), 481, 1978.

40. KONDRACKI J. Regional geography of Poland. PWN: Warszawa, pp. 441, 2009 [In Polish].

41. SZAFER W., PAWŁOWSKI B. Geobotanical division of Poland. In: Vegetation of Poland, T.2; Szafer W., Zarzycki K. (Ed.), Wydawnictwo Naukowe PWN: Warszawa, pp. 7880, 1972 [In Polish].

42. HUCULAK M. Rzeszów reservoir in Wisłok River. In: Encyclopedia of Rzeszów; Budzyński Z. (Ed.), Mitel: Rzeszów, pp. 263, 2011 [In Polish].

43. KUKUŁA K., BYLAK A. Special Areas of Conservation of habitat - Middle Wisłok River with tributary. In: Natura 2000 areas in Podkarpackie Voivodship; Rogała D., Marcela A. (Ed.), RDOŚ: Rzeszów, pp. 320-325, 2011 [In Polish].

44. ZIAJA M. Vascular flora of Rzeszów reservoir. Przegląd Naukowy Instytutu Wychowania Fizycznego i Zdrowotnego WSP: Rzeszów, 1, (2), 65, 1998 [In Polish].

45. MIREK Z., PIĘKOŚ-MIRKOWA H., ZAJĄC A., ZAJĄC M. Flowering plants and pteridophytes of Poland - a checklist. In: Biodiversity of Poland 1; Mirek Z. (Ed.), Polish Academy of Sciences, W. Szafer Institute of Botany: Kraków, pp. 442, 2002.

46. RUTKOWSKI L. The guide to determining of vascular plants in lowland Polish. Wydawnictwo Naukowe PWN: Warszawa, pp. 814, 2004 [In Polish].

47. ZARZYCKI K., TRZCIŃSKA-TACIK H., RÓŻAŃSKI W., SZELĄG Z., WOŁEK J., KORZENIAK U. Ecological indicators values of vascular plants of Poland. In: Biodiversity of Poland 2; Mirek Z. (Ed.), Polish Academy of Sciences, W. Szafer Institute of Botany: Kraków, pp. 183, 2002.

48. KORNAŚ J. Analysis of synanthropic floras. Wiad. Bot. 21, (2), 85, 1977 [In Polish]. 
49. ZAJAC M., ZAJAC A. A tentative list of segetal and ruderal apophytes in Poland. Zesz. Nauk. Uniwersytetu Jagiellońskiego, Prace Botaniczne 24, 7, 1992.

50. ZAJAC A. The origin of the archaeophytes occurring in Poland. Zesz. Nauk. Uniw. Jagiellońskiego, Rozpr. Habil. 29, 1-213, 1979 [In Polish].

51. ZAJAC A. Studies on the origin of archaeophytes in Poland. Part II. Taxa of Mediterranean and Atlantic-Mediterranean origin. Zesz. Nauk. UJ. Pr. Bot. 14, 7, 1987.

52. ZAJĄC A. Studies on the origin of archaeophytes in Poland. Part III. ZAJACC A. Studies on the origin of archeophytes in Poland. Part III. Irano-Turanian, Euro-Siberian-IranoTuranian and Mediterranean-Irano-Turanian origin. Zesz. Nauk. UJ. Pr. Bot. 15, 93, 1987.

53. ZAJAC A. Studies on the origin of archaeophytes in Poland. Part IV. Taxa of Pontic-Pannonian, Mediterraneo-South Asiatic, South Asiatic and middle European origin. Archaeophyta anthropogena. Archaeophyta resistentia. Archaeophytes of unknown origin. Zesz. Nauk. UJ. Pr. Bot. 17, 23, 1988.

54. JACKOWIAK B. Anthropogenic changes of the flora of vascular plants of Poznań. Wyd. Nauk, Uniw. Adama Mickiewicza: Poznań, Ser. Biol. 42, 1-232, 1990 [In Polish].

55. MATUSZKIEWICZ W. A guide to identification of plant communities of Poland. Vademecum geobotanicum, Wydawnictwo Naukowe PWN: Warszawa, pp. 537, 2002 [In Polish].

56. REGULATION OF THE MINISTER OF ENVIRONMENT of 5 January 2012. On the plant species protection. (J. Law. of 20 January 2012, Item. 81) [In Polish].

57. PIÓRECKI J. Trapa natans L. In: Polish Plant Red Data Book, Pteridophyta and Spermatophyta; Zarzycki K., Kaźmierczakowa R. (Ed.), Polish Academy of Sciences, W. Szafer Institute of Botany: Kraków, pp. 260-261, 2001 [In Polish].

58. ZARZYCKI K., SZELĄG Z. Red list of the vascular plants in Poland. In: Red list of plants and fungi in Poland; Mirek Z., Zarzycki K., Wojewoda W., Szeląg Z. (Eds.), Polish Academy of Sciences, W. Szafer Institute of Botany: Kraków, pp. 11-20, 2006

59. KUKUŁA K., BYLAK A., TABASZ S., KUBEJKO Ł. The largest population of water chestnut Trapa natans in the south-eastern Poland. Chrońmy Przyr. Ojcz. 69, (6), 535, 2013 [In Polish].

60. CHMIEL J. Spatial diversity of flora as a basis for nature conservancy in the agricultural landscape. Prace Zakładu Taksonomii Roślin UAM, Wyd. Nauk Bogucki: Poznań, 14, 5-250, 2006 [In Polish].

61. LYASHENKO G.F. Dynamics of Hydrophilic Phytocenoses in the Littoral of the Rybinsk Reservoir. Inland Water Biology 6, (1), 32, 2013.

62. POT R., TER HEERDT G.N.J. Succession dynamics of aquatic lake vegetation after restoration measures: increased stability after 6 years of development. Hydrobiologia 737, (1), 333, 2014.

63. HRUSKA K., DELL'UOMO A., STAFFOLANI L., TORRISI M. Influence of urbanization on riparian and algal species composition in two rivers of central Italy. Ecoscience 15, (1), 121, 2008.
64. CESCHIN S., SALERNO G., BISCEGLIE S., KUMBARIC A. Temporal floristic variations as indicator of environmental changes in the Tiber River in Rome. Aquat. Ecol. 44, (1), 93, 2010

65. FANELli G., TESCAROLLO P., TESTI A. indicators applied to urban and suburban flora. Ecological Indicators 6, (2), 444, 2006.

66. PYŠEK P., RICHARDSON D.M. Invasive species, environmental change and management, and health. Annual Reviews Environ. Resour. 35, 25, 2010.

67. KRISTENSEN E.A., KRONVANG B., WIBERGLARSEN P., THODSEN H., NIELSEN C., AMOR E., FRIBERG N., PEDERSEN M.L., BAATTRUP-PEDERSEN A. 10 years after the largest river restoration project in Northern Europe: Hydromorphological changes on multiple scales in River Skjern. Ecol. Eng. 66, 141, 2014.

68. HUSSNER A. Alien aquatic plant species in European countries. Weed Res. 52, (4), 297, 2012.

69. FLEMING J.P., DIBBLE E.D. Ecological mechanisms of invasion success in aquatic macrophytes. Hydrobiologia 2014. DOI 10.1007/s10750-014-2026-y

70. CHMIEL J. Flora of vascular plants of the eastern part of the Gniezno lake district and its transformation under the influence of man in the $19^{\text {th }}$ and $20^{\text {th }}$ centuries. Part I and II. Prace Zakładu Taksonomii Roślin Uniwersytetu im. A. Mickiewicza w Poznaniu: Poznań, Bogucki Wydaw. Nauk., I: 3-202, II: 5-215. 1993 [In Polish].

71. TOKARSKA-GUZIK B., WĘGRZYNEK B., URBISZ A., URBISZ A., NOWAK T., BZDĘGA K. Alien vascular plants in the Silesian Upland of Poland: distribution, patterns, impacts and threats. Biodiv. Res. Conserv. 19, 33, 2010.

72. BERNEZ I., AGUIAR F., VIOLLE C., FERREIRA T. Invasive river plants from Portuguese floodplains: What can species attributes tell us? Hydrobiologia 570, (1), 3, 2006.

73. BRUNDU G. Plant invaders in European and Mediterranean Island waters: profiles, distribution, and threats. Hydrobiologia 2014. DOI 10.1007/s10750-014-1910-9

74. JACKOWIAK B. Models of the expansion of synanthropic and transgenic plants. Phytocoenosis 11 (N.S.), Seminarium Geobot. 6, 4, 1999 [In Polish].

75. MÉNDEZ-TORIBIO M., ZERMEÑO-HERNÁNDEZ I., IBARRA-MANRÍQUEZ G. Effect of land use on the structure and diversity of riparian vegetation in the Duero river watershed in Michoacán, Mexico. Plant. Ecol. 215, (4), 285, 2014.

76. DE BECKER P., HERMY M., BUTAYE J. Ecohydrological characterization of a groundwater-fed alluvial floodplain mire. Appl. Veg. Sci. 2, 215, 1999.

77. WERNER K.J., ZEDLER J.B. How sedge meadow soils, microtopography, and vegetation respond to sedimentation. Wetlands 22, 451, 2002.

78. WIENS J.A. Riverine landscapes: taking landscape ecology into the water. Freshwater Biol. 47, (4), 501, 2002.

79. SUGIER P., LORENS B., CHMIEL S., TURCZYŃSKI M. The influence of Ceratophyllum demersum L. and Stratiotes aloides $\mathrm{L}$. on richness and diversity of aquatic vegetation in the lakes of mid-eastern Poland. Hydrobiologia 656, (1), 43, 2010. 